\title{
Technical note: Validation of an ELISA for measurement of tumor necrosis factor alpha in bovine plasma
}

\author{
J. K. Farney, L. K. Mamedova, B. H. Godsey, and B. J. Bradford ${ }^{1}$ \\ Department of Animal Sciences and Industry, Kansas State University, Manhattan 66506
}

\begin{abstract}
Tumor necrosis factor $\alpha(\mathrm{TNF} \alpha)$ is an inflammatory cytokine that is involved in immune function and is proposed to play a role in metabolic disorders. Although some bovine-specific methods have been published recently, assays used for determining plasma $\mathrm{TNF} \alpha$ concentration in bovine disease models often do not offer acceptable precision for measurement of basal concentrations in healthy animals. The objective of this work was to develop an effective, low-cost sandwich ELISA procedure with improved sensitivity. A protocol developed for use with cell culture supernatant was modified for use with bovine plasma and serum by optimizing antibody concentrations, incubation times and temperatures, and standard diluents. The coating antibody concentration was decreased from 10 to 6.8 $\mu \mathrm{g} / \mathrm{mL}$, whereas the detection antibody concentration remained $2.5 \mu \mathrm{g} / \mathrm{mL}$. Sample incubation was increased from $1 \mathrm{~h}$ at room temperature to an overnight incubation at $4^{\circ} \mathrm{C}$, which increased the sensitivity of the assay. Multiple matrices were tested for dilution of standards and were assessed by determining recovery of bovine TNF $\alpha$ spiked into bovine serum and plasma. Recoveries were acceptable in both bovine serum and plasma (71-103\%) when quantified with standards diluted in human serum or phosphate-buffered saline. The modified bovine TNFa ELISA offers a detection range of 2 to $250 \mathrm{pg} / \mathrm{mL}$. This detection limit is at least an order of magnitude lower than previously reported, and will allow for greater precision in determining basal $\mathrm{TNF} \alpha$ concentrations in bovine plasma. The improved sensitivity of this ELISA will be critical to assessing current hypotheses concerning the metabolic effects of moderately elevated $\mathrm{TNF} \alpha$ concentrations.
\end{abstract}

Key words: tumor necrosis factor $\alpha$, bovine, ELISA

Received December 10, 2010.

Accepted March 30, 2011

${ }^{1}$ Corresponding author: bbradfor@ksu.edu

\section{Technical Note}

In recent years, the role of cytokines in immunity, inflammation, and metabolism have attracted increasing attention in the animal sciences. Tumor necrosis factor $\alpha(\mathbf{T N F} \boldsymbol{\alpha})$, in particular, is of interest because it represents one potential mediator linking infectious and metabolic diseases. Infectious diseases such as mastitis and metritis (Sordillo et al., 2009) can cause systemic increases in TNFo, which may, in turn, promote the development of fatty liver and associated metabolic problems (Bradford et al., 2009).

Research on the role of TNF $\alpha$ in bovine physiology has been slowed by a lack of commercially available analytical reagents. Although human and bovine forms of $\mathrm{TNF} \alpha$ share approximately $80 \%$ sequence homology, numerous anti-human $\mathrm{TNF} \alpha$ antibodies failed to detect bovine TNFo (bTNF $\alpha$; Dernfalk et al., 2004). Kenison and colleagues (1990) generated anti-bTNFo serum for use in a competitive radioimmunoassay, and this assay has subsequently been used in several key studies (Daniel et al., 2003; Elsasser et al., 2005). However, broad use of this approach is difficult because the reagents are not commercially available and because it requires radioimmunoassay capabilities, including facilities for protein iodination.

Bovine-specific reagents for measurement of $\mathrm{TNF} \alpha$ have become commercially available (bTNFa ELISA; Bovine TNFa Screening Set; Thermo Fisher Scientific Inc., Rockford, IL); however, the protocols published are for cell culture supernatants, not bovine serum or plasma. Additionally, TNFo in bovine plasma was measured using a human ELISA kit (hTNF $\boldsymbol{\alpha}$ ELISA; cata$\log$ \#589201; Cayman Chemical Co., Ann Arbor, MI) to relate its concentration in periparturient cows with incidence of fatty liver (Ametaj et al., 2005). However, this kit was not validated for use with bovine samples. Our goal in this work was to evaluate the validity of both ELISA kits for measurement of bTNFo in plasma. An additional goal was to develop a low-cost, precise method for measurement of TNFo in bovine serum and plasma with adequate sensitivity to detect basal levels of TNFa. All experimental procedures were approved 
by the Kansas State University Institutional Animal Care and Use Committee.

To produce a protein standard for evaluation of ELISA assays, a recombinant expression vector encoding the secreted form of bTNFo (Entrez Protein Accession AAB84086.1, region 77-233; http://www.ncbi. nlm.nih.gov/protein) was expressed in Escherichia coli and purified by a commercial laboratory. Purity and biological activity of the isolated recombinant $\mathrm{bTNF} \alpha$ were verified by SDS-PAGE and a WEHI 13Var-164based assay, respectively. Several commercial sources of recombinant bTNF $\alpha$ exist, and it is expected that all such standards would work equally well for the purpose of this ELISA assay; evaluating these standards was outside the scope of this study.

The specificity of the polyclonal rabbit anti-bovine TNFo antibody was initially evaluated by Western blot analysis of bovine plasma proteins. Plasma samples $(1 \mu \mathrm{L})$ collected from cows receiving continuous lowdose infusions of recombinant bTNFa (concentrations ranging from $\sim 5$ to $35 \mathrm{pg} / \mathrm{mL}$ ) were diluted with 19 $\mu \mathrm{L}$ of Laemmli sample buffer (Bio-Rad Laboratories Inc., Richmond, CA). The homogenate was heated at $90^{\circ} \mathrm{C}$ for $5 \mathrm{~min}$, cooled, vortexed, and loaded onto a 4 to $20 \%$ Tris- $\mathrm{HCl}$ gel for electrophoresis. Samples were separated by SDS-PAGE and dry-transferred onto nitrocellulose membranes (iBlot; Invitrogen, Carlsbad, $\mathrm{CA}$ ). Membranes were blocked for $2 \mathrm{~h}$ in blocking buffer $(5 \%$ dry milk in Tris-HCl buffer, $\mathrm{pH} 7.5$, with $0.05 \%$ Tween 20). After incubation with blocking buffer, the membranes were washed 3 times for 5 min each with washing buffer (PBS, pH 7.5, containing $0.05 \%$ Tween 20 ), then incubated for $1 \mathrm{~h}$ with the biotin-conjugated polyclonal rabbit antibody (detection antibody, PBOTNFABI; Thermo Fisher Scientific Inc.) diluted 20,000fold in blocking buffer. After incubation, membranes were rinsed 3 times with washing buffer and then incubated for $1 \mathrm{~h}$ with horseradish peroxidase-labeled streptavidin diluted 50,000-fold in blocking buffer. Immunodetection was performed by chemiluminescence (West-Dura; Thermo Scientific, Waltham, MA).

Western blot results (Figure 1A) showed that the detection antibody used in the bTNF $\alpha$ ELISA detected a single band in plasma with the expected molecular weight of bTNFa $(\sim 17 \mathrm{kDa})$. The lack of other bands suggests that cross-reactivity of the antibody with other common proteins found in bovine plasma is likely to be minimal. The product literature notes that approximately $2 \%$ cross-reactivity with bovine IL- 6 was detected with the bTNFa ELISA, but no other bovine cross-reactivities were reported. We conclude that the specificity of the bTNFo ELISA antibodies are sufficient for use in plasma samples.
The bTNFa ELISA kit originally included suggested protocols for determination of bovine $\mathrm{TNF} \alpha$ in cell culture media (screening kit protocol no longer available online), and did not include information regarding precision of the assay for concentrations typically found in bovine plasma $(\leq 300 \mathrm{pg} / \mathrm{mL}$; Kenison et al., 1991). We, therefore, tested a variety of primary and secondary antibody concentrations to determine the optimal protocol for determination of basal TNFo concentrations in bovine plasma, with the goal of achieving a low detection limit and an assay range of at least 2 orders of magnitude. The optimal concentration of coating antibody was determined to be $6.8 \mu \mathrm{g} / \mathrm{mL}$, whereas the optimal concentration of detection antibody was $2.5 \mu \mathrm{g} / \mathrm{mL}$ (data not shown).

The final protocol was as follows. First, a 96-well plate (Corning Costar high-binding 96-well plate; Thermo Fisher Scientific Inc.) was coated with $100 \mu \mathrm{L}$ of coating antibody (polyclonal rabbit anti-bovine TNF $\alpha$, PBOTNFAI; Thermo Fisher Scientific Inc.) at a concentration of $6.8 \mu \mathrm{g} / \mathrm{mL}$ diluted in $0.2 \mathrm{M}$ sodium-bicarbonate buffer ( $\mathrm{pH} 9.4 ; 0.2 \mu \mathrm{m}$ filtered). The plate was then sealed and incubated overnight at room temperature. On the next day, the wells were aspirated and then washed 5 times with wash buffer $(0.05 \%$ Tween 20 and $0.1 \%$ sodium azide in PBS). Following the wash steps, 300 $\mu \mathrm{L}$ of blocking buffer (4\% BSA, $5 \%$ sucrose in PBS, $0.2 \mu \mathrm{m}$ filtered) was added to the wells and incubated for $2 \mathrm{~h}$ at room temperature. The wells were aspirated and again washed with wash buffer 5 times, and then samples $(100 \mu \mathrm{L})$ and standards $(100 \mu \mathrm{L}$ at concentrations $200,50,12.5$, and $3.125 \mathrm{pg} / \mathrm{mL}$ in human serum) were added to the wells. Human serum was added to nonspecific binding and $0 \mathrm{pg} / \mathrm{mL}$ standard wells. The samples were allowed to incubate overnight at $4^{\circ} \mathrm{C}$. On the third day of the procedure, the wells were washed 5 times with wash buffer, followed by addition of $100 \mu \mathrm{L}$ of detection antibody (biotin labeled polyclonal rabbit anti-bovine TNFo, PBOTNFABI; Thermo Fisher Scientific Inc.) at a concentration of $2.5 \mu \mathrm{g} / \mathrm{mL}$, then allowed to incubate for $1 \mathrm{~h}$. After the incubation period, the plates were again washed 5 times; then, $100 \mu \mathrm{L}$ of horseradish peroxidase-labeled streptavidin (diluted 1:500 in reagent diluent; HRP-conjugated streptavidin; Thermo Fisher Scientific Inc.) was added to each well and incubated at room temperature for $30 \mathrm{~min}$, followed by another round of 5 washes with wash buffer. Finally, $100 \mu \mathrm{L}$ of $3,3^{\prime}, 5,5^{\prime}$-tetramethylbenzidine substrate solution (TMB Solution; Thermo Fisher Scientific Inc.) was added to each well and allowed to incubate for $20 \mathrm{~min}$ at room temperature, followed by the addition of 100 $\mu \mathrm{L}$ of stop solution (0.18 $M$ sulfuric acid). The optical density was measured at 450 and $550 \mathrm{~nm}$ using a plate 
A.

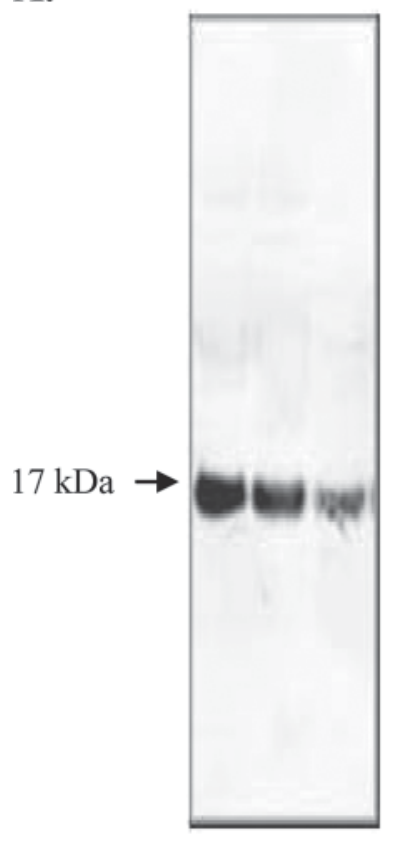

B.

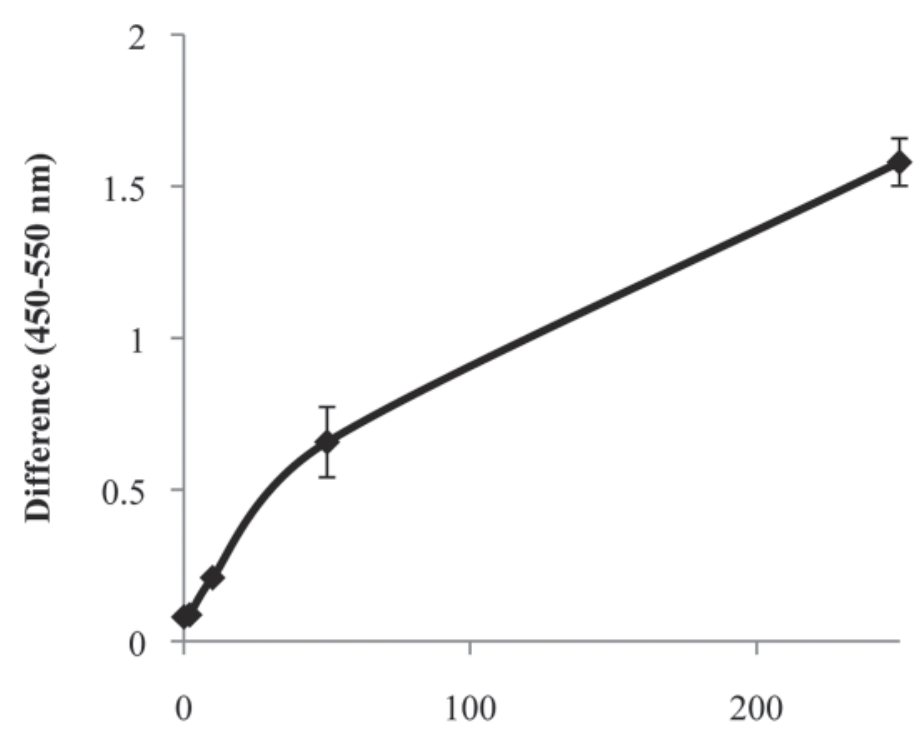

$\mathrm{TNF} \alpha$ concentration $(\mathrm{pg} / \mathrm{mL})$

C.

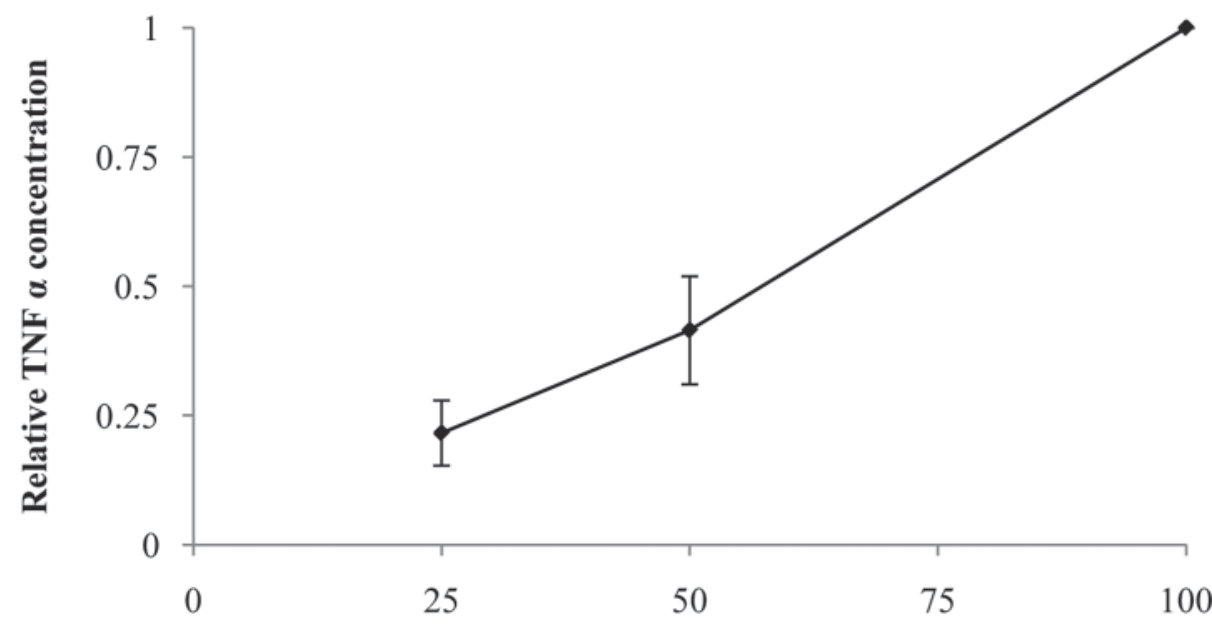

Plasma sample volume $(\%)$

Figure 1. Characteristics of the bovine-specific ELISA assay. (A) Western blot analysis of tumor necrosis factor $\alpha$ (TNF $\alpha$ ) protein in bovine plasma ( $1 \mu \mathrm{L}$ per lane) using the bovine-specific ELISA detection antibody. The Western blot image shows bands corresponding to bovine TNFo (bTNFo; $17 \mathrm{kDa}$ ), with no other proteins apparently detected. (B) A typical standard curve utilizing bovine-specific antibodies and recombinant bTNFo diluted in human serum is shown. Values are means \pm standard deviations of standards plated in triplicate. (C) Linearity of the assay was assessed by linearly decreasing sample volume. Bovine plasma samples $(\mathrm{n}=10)$ were plated in duplicate at each of 3 sample volumes $(20,10$, and $5 \mu \mathrm{L}$ per well). Within sample, concentrations of the $20-\mu \mathrm{L}$ samples were scaled to 1 , and the lower volume concentrations scaled accordingly. Points represent the mean \pm standard deviation; a linear regression of the plot generated the equation $\mathrm{y}=1.063 \mathrm{x}-0.076$.

reader (PowerWaveXS; BioTek Instruments Inc., Winooski, VT). Also, Gen5 software (BioTek Instruments Inc.) was used to calculate the concentration of $\mathrm{TNF} \alpha$ in the samples by calculating the difference between the $\mathrm{A}_{450}$ and $\mathrm{A}_{550}$. The $\mathrm{A}_{450}-\mathrm{A}_{550}$ values were corrected by subtracting the mean value for nonspecific binding wells from all other values. The corrected difference values were fit to the standard curve by point-to-point regression.

With this protocol, we were able to detect bTNFa concentrations in a range from 2 to $250 \mathrm{pg} / \mathrm{mL}$. After reviewing the literature, only one protocol emerged that had a similar detection limit in bovine serum/ plasma; the sandwich ELISA protocol described by 
Table 1. Apparent recovery of recombinant bovine tumor necrosis factor $\alpha$ ( $\mathrm{rbTNF} \alpha)$ spiked into bovine serum or plasma, as assessed using various standard curve diluents ${ }^{1}$

\begin{tabular}{lll}
\hline & & Regression equation \\
\cline { 2 - 3 } Diluent type & Serum & Plasma \\
\hline Dialyzed $\mathrm{FBS}^{2}$ & $\mathrm{y}=0.28 \mathrm{x}+1.01$ & $\mathrm{y}=0.42 \mathrm{x}+0.82$ \\
FBS & $\mathrm{y}=0.49 \mathrm{x}+1.93$ & $\mathrm{y}=0.70 \mathrm{x}-2.53$ \\
Human plasma & $\mathrm{y}=1.02 \mathrm{x}-22.65$ & $\mathrm{y}=1.54 \mathrm{x}-21.57$ \\
Human serum & $\mathrm{y}=0.71 \mathrm{x}+2.41$ & $\mathrm{y}=0.96 \mathrm{x}+4.98$ \\
Lyophilized bovine plasma & $\mathrm{y}=1.89 \mathrm{x}-14.54$ & $\mathrm{y}=1.97 \mathrm{x}+9.30$ \\
Lyophilized human plasma & $\mathrm{y}=0.99 \mathrm{x}-21.96$ & $\mathrm{y}=1.60 \mathrm{x}-25.54$ \\
Lyophilized human serum & $\mathrm{y}=0.88 \mathrm{x}-0.75$ & $\mathrm{y}=1.19 \mathrm{x}+0.66$ \\
PBS & $\mathrm{y}=0.85 \mathrm{x}+2.91$ & $\mathrm{y}=1.02 \mathrm{x}+13.61$ \\
\hline
\end{tabular}

${ }^{1}$ Equations derived from plots of spiked $\operatorname{rbTNF} \alpha(\mathrm{x})$ against observed TNFo concentrations (y), both in $\mathrm{pg} /$ $\mathrm{mL}$.

${ }^{2}$ Fetal bovine serum.

Ellis et al. (1993) had a detection limit of $35 \mathrm{pg} / \mathrm{mL}$ in bovine serum. Other protocols in previous $\mathrm{bTNF} \alpha$ ELISA studies reported basal plasma concentrations that were likely inflated by poor sensitivity of the assays (133-15,630 pg/mL: Hisaeda et al., 2001; Røntved et al., 2005; Burciaga-Robles et al., 2010).

One challenge in developing ELISA protocols is to find a diluent for standards that mimics the matrix effect of plasma or serum. For example, Dernfalk et al. (2004) observed that the apparent recovery of recombinant hTNFo added to bovine serum was only $36.4 \%$ of the apparent recovery when recombinant hTNF $\alpha$ was added to a buffer solution. Therefore, standards were prepared in a variety of diluents, and standard curves were generated. These were then used to quantify known concentrations of recombinant bTNFo that were spiked into serum and plasma from healthy cattle. Table 1 shows the different diluents used and the apparent recovery of the spiked in recombinant bTNFa. Based on these results, we suggest that PBS and human serum can serve as valid standard diluents for both bovine serum and plasma analyses. We also tested the difference in $\mathrm{TNF} \alpha$ concentrations in plasma and serum collected at the same time from 8 cows with detectable $\mathrm{TNF} \alpha$ to determine if the concentrations were similar. We observed no significant difference $(P>0.10)$ between bovine serum and plasma samples (means: 3.59 vs. $4.92 \pm 0.88 \mathrm{pg} / \mathrm{mL}$ in plasma vs. serum, $\mathrm{n}=$ $8)$. Thus, the procedure appears to be equally useful for either sample type. However, the type of sample collected could influence the choice of standard curve diluent (Table 1).

This ELISA procedure was used across 10 plates to test the precision of the assay when using human serum as the standard diluent. The intra-assay coefficient of variation values at specific concentrations are shown in Table 2 and a typical standard curve is shown in Figure 1B. Pooled samples were included on each plate to de- termine inter-assay coefficients of variation, which were 13.9 and $10.4 \%$ for serum and plasma, respectively. Linearity of the assay was tested using plasma samples $(\mathrm{n}=10)$ with relatively high concentrations of $\mathrm{TNF} \alpha$ $(605 \pm 253 \mathrm{pg} / \mathrm{mL}$, mean $\pm \mathrm{SD})$. Samples were plated in duplicate at each of 3 volumes $(20,10$, and $5 \mu \mathrm{L}$ per well). To ease data interpretation, concentrations within sample were divided by the result for the highest sample volume $(20 \mu \mathrm{L}=100 \%)$. The slope of the resulting regression equation (1.06; Figure 1C) suggests that the assay produces unbiased results across the range of the assay (14-199 $\mathrm{pg} / \mathrm{mL}$ for these samples).

Additionally, we tested the ability of this assay to detect physiological changes in TNFo concentrations in a model mimicking a disease scenario. To accomplish this, plasma samples from cows that were injected i.v. with recombinant bTNFo $(5 \mu \mathrm{g} / \mathrm{kg}$ of BW $)$ were used in this assay. Samples $(\mathrm{n}=8$ per time point) collected immediately before and at 1,2 , and $3 \mathrm{~h}$ post-infusion (diluted with human serum when necessary) were assayed for TNFo. The assay was able to detect a highly significant increase in plasma TNF $\alpha$ concentrations $(P$ $<0.001$; Figure 2) in spite of the fact that the mean concentration at $1 \mathrm{~h}$ post-infusion remained below the detection limit for most bovine TNF $\alpha$ assays.

We were interested in determining if $b T N F \alpha$ is detectable by human $\mathrm{TNF} \alpha$ antibodies, especially because of previously-reported associations between fatty liver disease and bTNFo determined using an hTNF $\alpha$

Table 2. Average intra-assay coefficient of variation from 10 plates

\begin{tabular}{lc}
\hline $\begin{array}{l}\text { Concentration } \\
(\mathrm{pg} / \mathrm{mL})\end{array}$ & $\mathrm{CV}$ \\
& $(\%)$ \\
\hline 200 & 2.58 \\
50 & 12.66 \\
12.5 & 13.00 \\
3.125 & 23.61 \\
\hline
\end{tabular}




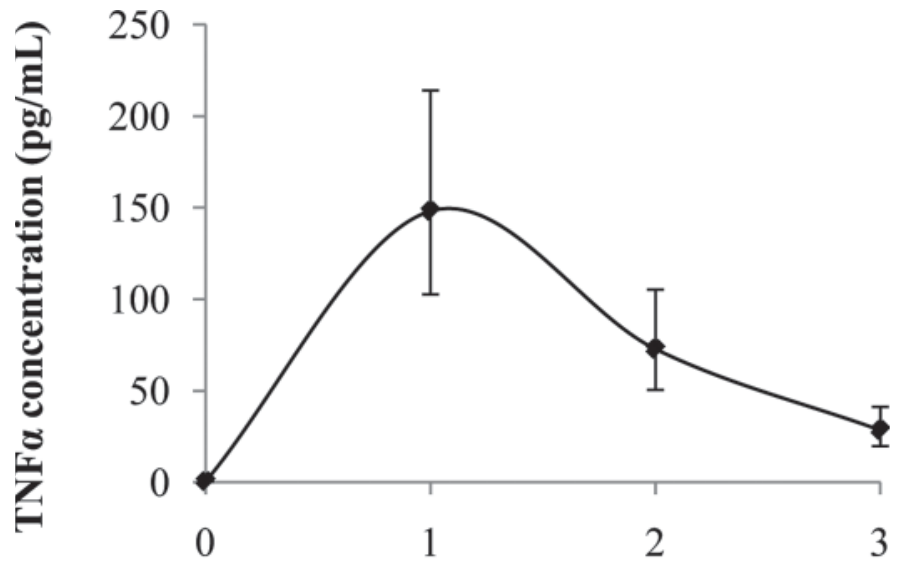

Time postinfusion (h)

Figure 2. Changes in bovine plasma tumor necrosis factor $\alpha$ $(\mathrm{bTNF} \alpha)$ in response to recombinant bTNFo (rbTNFa) injection. Lactating cows were administered an i.v. bolus of rbTNFo $(5 \mu \mathrm{g} / \mathrm{kg}$ of BW) immediately after a blood sample was collected (time $0 \mathrm{~h}$ ). Blood samples were collected at 1,2 , and $3 \mathrm{~h}$ postinfusion. Plasma samples were analyzed using the bTNFo ELISA. Values are means \pm standard error of the means $(n=8)$; values were log-transformed for analysis and means shown are back-transformed. The effect of time was significant $(P<0.001)$.

ELISA (Ametaj et al., 2005). We used the same kit as Ametaj et al. (2005; Catalog \#589201; Cayman Chemical Co.) to determine whether the anti-hTNFo antibodies employed in the kit would detect recombinant bTNFo. We added human and bovine TNFo to the kit's standard diluent and carried out the assay according to the manufacturer's directions. The results showed that the recombinant bTNFa protein did not cross-react with the human antibodies (Figure 3A). Another paper reported similar findings when human $\mathrm{TNF} \alpha$ antibodies were used in an attempt to detect recombinant $\mathrm{bTNF} \alpha$ and recombinant ovine $\mathrm{TNF} \alpha$ in bovine milk and serum samples (Dernfalk et al., 2004). The authors observed no cross-reactivity with recombinant $\mathrm{bTNF} \alpha$, and recombinant ovine $\mathrm{TNF} \alpha$ was only detectable at concentrations greater than $2.5 \mathrm{ng} / \mathrm{mL}$.

Although we were unable to detect recombinant bTNFo with the hTNF $\alpha$ ELISA kit, the original report (Ametaj et al., 2005) demonstrated differences across time, and we also clearly detected some immunoreactive protein in bovine plasma using this assay. To further assess whether the hTNF $\alpha$ ELISA kit was detecting $\mathrm{bTNF} \alpha$, the detection antibody from the human TNF $\alpha$ kit was used in a Western blot. Serum samples $(1 \mu \mathrm{L})$ collected from early lactation dairy cows (concentrations ranging from $\sim 2$ to $9 \mathrm{pg} / \mathrm{mL}$ ) and a $1-\mu \mathrm{L}$ aliquot of recombinant bTNFo $(0.58 \mu \mathrm{g} / \mathrm{mL})$ were diluted with Laemmli sample buffer (Bio-Rad Laboratories
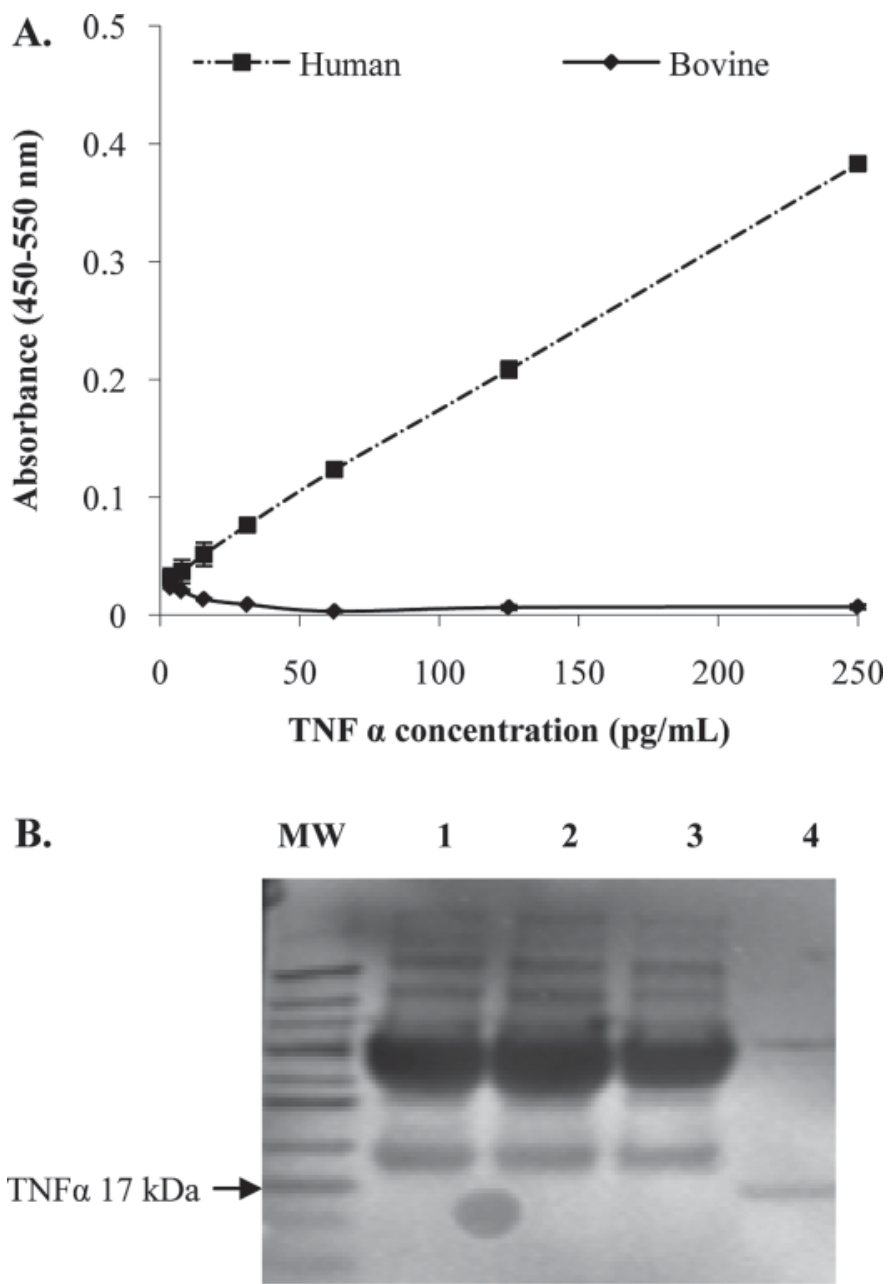

Figure 3. Human tumor necrosis factor $\alpha$ (TNF $\alpha)$ ELISA does not detect bovine TNF . (A) Recombinant bovine TNFo was used to test cross-reactivity of a human TNFo ELISA kit (Cayman Chemical Co., Ann Arbor, MI). The assay was performed according to the manufacturer's instructions, and bovine standards were diluted to match those of the human TNF $\alpha$ standard curve. Values are means \pm standard deviations (error bars are too small to be seen for most points). (B) Western blot analysis of $\mathrm{TNF} \alpha$ protein in bovine serum using the antihuman TNFo detection antibody. Lanes are as follows: MW = protein ladder $(8 \mu \mathrm{L}$, Novex Sharp Protein Standard; Invitrogen, CA; standards at $260,160,110,80,60,50,40,30,20,15$, and $10 \mathrm{kDa}$ ); lanes 1 to $3=$ bovine serum $(1 \mu \mathrm{L}$ diluted with $19 \mu \mathrm{L}$ of Laemmli buffer $)$; lane $4=0.58 \mathrm{ng}$ of recombinant bovine TNFo. The results demonstrated that the antibody did not detect the bovine form of $\mathrm{TNF} \alpha$ with reasonable specificity.

Inc.) and prepared as described above. The Western blot was carried out according to the same procedure described above, but used the TNFo AChE:Fab' antibody (TNFo acetylcholinexterase:Fa; hTNFo EIA Kit; Cayman Chemical Co.), diluted 10,000-fold in blocking buffer in the overnight incubation. The results (Figure 3B) showed strong bands between 50 and $60 \mathrm{kDa}$, indicating that the detection antibody in the kit is able to detect some protein in bovine plasma. However, only 
very faint bands were observed at $17 \mathrm{kDa}$, even for the purified protein, suggesting that this antibody is a poor probe for bovine TNFa. With the findings from this series of experiments, it seems unlikely that the protein detected by Ametaj et al. (2005) was TNF $\alpha$, and the previous results, therefore, need to be re-evaluated.

In conclusion, the procedure described herein provides a useful tool to determine basal concentrations of bovine TNF $\alpha$, which are often below $10 \mathrm{pg} / \mathrm{mL}$. This improved sensitivity should aid in determining the roles of $\mathrm{TNF} \alpha$ in bovine metabolism and chronic diseases.

\section{ACKNOWLEDGMENTS}

Contribution no. 11-152-J from the Kansas Agricultural Experiment Station. This project was supported by National Research Initiative Competitive Grant no. 2009-35206-05271 from the USDA National Institute of Food and Agriculture.

\section{REFERENCES}

Ametaj, B. N., B. J. Bradford, G. Bobe, R. A. Nafikov, Y. Lu, J. W. Young, and D. C. Beitz. 2005. Strong relationships between mediators of the acute phase response and fatty liver in dairy cows. Can. J. Anim. Sci. 85:165-175.

Bradford, B. J., L. K. Mamedova, J. E. Minton, J. S. Drouillard, and B. J. Johnson. 2009. Daily injection of tumor necrosis factor- $\alpha$ increases hepatic triglycerides and alters transcript abundance of metabolic genes in lactating dairy cattle. J. Nutr. 139:1451-1456.

Burciaga-Robles, L. O., D. L. Step, C. R. Krehbiel, B. P. Holland, C. J. Richards, M. A. Montelongo, A. W. Confer, and R. W. Fulton.
2010. Effects of exposure to calves persistently infected with bovine viral diarrhea virus type $1 \mathrm{~b}$ and subsequent infection with Mannheima haemolytica on clinical signs and immune variables: Model for bovine respiratory disease via viral and bacterial interaction. J. Anim. Sci. 88:2166-2178.

Daniel, J. A., T. H. Elsasser, C. D. Morrison, D. H. Keisler, B. K. Whitlock, B. Steele, D. Pugh, and J. L. Sartin. 2003. Leptin, tumor necrosis factor- $\alpha$ (TNF), and CD14 in ovine adipose tissue and changes in circulating TNF in lean and fat sheep. J. Anim. Sci. 81:2590-2599.

Dernfalk, J., K. P. Waller, and A. Johannisson. 2004. Commercially available antibodies to human tumour necrosis factor- $\alpha$ tested for cross-reactivity with ovine and bovine tumour necrosis factor- $\alpha$ using flow cytometric assays. Acta Vet. Scand. 45:99-107.

Ellis, J. A., D. Godson, M. Campos, M. Sileghem, and L. A. Babiuk. 1993. Capture immunoassay for ruminant tumor necrosis factor- $\alpha$ : Comparison with bioassay. Vet. Immunol. Immunopathol. $35: 289-300$.

Elsasser, T. H., J. W. Blum, and S. Kahl. 2005. Characterization of calves exhibiting a novel inheritable TNF- $\alpha$ hyperresponsiveness to endotoxin: Associations with increased pathophysiological complications. J. Appl. Physiol. 98:2045-2055.

Hisaeda, K., K. Hagiwara, J. Eguchi, H. Yamanaka, R. Kirisawa, and H. Iwai. 2001. Interferon-gamma and tumor necrosis factor-alpha levels in sera and whey of cattle with naturally occurring coliform mastitis. J. Vet. Med. Sci. 63:1009-1011.

Kenison, D. C., T. H. Elsasser, and R. Fayer. 1990. Radioimmunoassay for bovine tumor necrosis factor: Concentrations and circulating molecular forms in bovine plasma. J. Immunoassay 11:177-198.

Kenison, D. C., T. H. Elsasser, and R. Fayer. 1991. Tumor necrosis factor as a potential mediator of acute metabolic and hormonal responses to endotoxemia in calves. Am. J. Vet. Res. 52:1320-1326.

Røntved, C. M., J. B. Anderson, J. Dernfalk, and K. L. Ingvartsen. 2005. Effects of diet energy density and milking frequency in early lactation on tumor necrosis factor-alpha responsiveness in dairy cows. Vet. Immunol. Immunopathol. 104:171-181.

Sordillo, L. M., G. A. Contreras, and S. L. Aitken. 2009. Metabolic factors affecting the inflammatory response of periparturient dairy cows. Anim. Health Res. Rev. 10:53-63. 